\title{
Peningkatan Keteramplian Listening Bagi Dosen Calon Peserta Tes Toep/PLTI Di Lingkungan Universitas Wiraraja Melalui Pelatihan Pengayaan Kosa Kata Dalam Media Audio Visual
}

\author{
Oleh : \\ Akhmad Feri Fatoni ${ }^{1)}$, Nisfil Maghfiroh Meita ${ }^{2)}$ \\ 1) Fakultas Keperawatan, Universitas Wiraraja, ${ }^{2}$ Fakultas Keguruan dan Ilmu Pendidikan, \\ Universitas Wiraraja
}

Email : Akhmadferi@wiraraja.ac.id ${ }^{1)}$, Nisfil@wiraraja.ac.id ${ }^{2)}$

\begin{abstract}
Abstrak
Pentingnya penguasaan bahasa Inggris tidak terlepas dari pelaksanaan tes bahasa Inggris berskala internasional seperti TOEP/TOEFL. Seperti diketahui bahwa pelaksanaan tes berskala internasional tersebut sering menjadi acuan kelulusan dosen untuk mendapat sertifikasi dosen. Namun fakta yang terjadi di Universitas Wiraraja dihimpun dari Badan Kepegawaian Univesitas Wiraraja, pada awal tahun 2020 dari sebanyak 144 dosen tetap hanya sekitar.49 dosen yang telah mendapatkan sertifikasi. Minimnya kelulusan dosen dalam mengikuti tes PLTI dikarenakan sebagian besar peserta mengalami kesulitan terlebih ketika mengerjakan tes listening. Hal ini dikarenakan minimnya penguasaan kosa kata bahasa Inggris. Menurut Fatoni (2020), penguasaan kosa kata sangat mempengaruhi keterampilan mendengarkan bahsa Inggris. Salah satu alternatif pembelajaran yang dapat dilakukan untuk membantu pembelajar meningkatkan keterampilan listening adalah dengan pembelajaran menggunakan audio visual. Pembelajaran dengan menggunakan audio visual merupakan metode efisien yang dapat meningkatkan kemampuan listening sekaligus memperkaya penguasaan kosa kata bahasa Inggris. Materi yang digunakan dalam pembelajaran adalah percakapan aktivitas sehari-hari dan disuguhkan dengan visualisasi kronologi kejadiannya disertai subtitle dan dikemas dalam bentuk tes/soal. Tujuan PkM ini adalah untuk meningkatkan keterampilan mendengarkan bahasa Inggris masyarakat sasaran. Sehingga mereka lebih mudah dalam menghadapi soal listening. Manfaat pengabdian kepada masyarakat ini adalah untuk meningkatkan kuantitas dosen yang mendapat sertifikasi di lingkungan Universitas Wiraraja. Selain itu melalui pengabdian ini akan dihasilkan modul materi peningkatan keterampilan listening dan trik mengerjakan soal. Kegiatan yang dilaksanakan hingga pertemuan kelima mengindikasikan bahwa rangkaian kegiatan telah mencerminkan tujuan PkM. Pada akhir pertemuan, mayoritas peserta PkM mengalami peningkatan keterampilan mengerjakan soal listening
\end{abstract}

Kata Kunci: Keterampilan listening, Penguasaan kosa kata, Audio visual

\section{Pendahuluan}

Keterampilan berkomunikasi bahasa Inggris sebagai bahasa Internasional sangat dibutuhkan terlebih menghadapi era persaingan global. kebutuhan peningkatan berbahasa Inggris dibutuhkan tidak hanya bagi kalangan siswa (pembelajar), tetapi juga bagi dosen (pengajar) untuk berbagai keperluan. Bagi dosen, kemahiran berbahasa Inggris dibutuhkan salah satunya sebagai syarat lulus sertifikasi dosen. Kelulusan dalam mengikuti tes sertifikasi dosen dapat ditempuh dengan dengan mengikuti tes PLTI (Pusat Layanan Tes Indonesia) dengan komposisi tes TOEP dan TKDA. Pada tahun 
memahami model-model soal listening Sehingga mereka kerap terkecoh oleh soal yang sebenarnya mudah untuk dicerna.

Pada sisi lain, peserta tes TOEP/PLTI adalah dosen yang fokus pendidikannya adalah berbagai macam disiplin ilmu. Atas kesibukan memenuhi Tridaharma perguruan tingi, kesempatan dan kemungkinan ntuk mempelajari keterampilan listening bahasa Inggris sangat terbatas. Oleh karena itu, sangat dibutuhkan metode yang dapat membantu para dosen calon peserta tes TOEP/PLTI untuk menigkatkan kemampuan mendengarkan dengan menitik beratkan pada penguasaan kosa kata.

Listening adalah satu dari empat keterampilan dalam bahasa Inggris yang digolong dalam receiptive skill. Artinya, ketika pendengar disuguhkan materi atau soal, maka mereka harus menitik beratkan fokus pada materi tersebut. Liubiniene (2009) menjelaskan bahwa keterampilan listening (mendengarkan) adalah keterampilan utama untuk memahami komunikasi. Dalam proses listening, pendengar harus memahami, mengapresiasi, serta mengevaluasi materi yang dikomunikasian.

Kegiatan mendengarkan merupakan hal kompleks, mulai dari proses hingga tujuan kegiatan mendengarkan sendiri. Tarigan (2006) mengklasifikasikan beberapa jenis listening berdasarkan tujuannya, yaitu ekstensf dan intensif. Berkaitan dengan kebutuhan listening untuk mengadapi ujian TOEP/PLTI, maka proses mendengarkan materi harus dilakukan secara intensif agar pendegar dapat menangkap informasi yang dikehendaki. 
trik bagaimana cara memahami soal ketika teks ditayangkan secara visual

\section{Metode Pelaksanaan} besar dosen mengikuti tes PLTI melalui teknis TFH( Test From Home) dengan pencapaian skor melebihi target kelulusan. Oleh karenanya mitra sasaran pada PkM ini dialihkan pada dosen berNIDN. Dikarenakan permasalah yang tengah dihadapi oleh dosen berNIDN calon peserta TOEP/PLTI di lingkungan Universitas Wiraraja merupakan masalah krusial dan perlu untuk dipecahkan, maka dibutuhkan pengaplikasian metode latihan yang bersifat modern dan sesuai dengan perkembangan zaman agar peserta lebih mudah memahami ragam kosa kata bahasa Inggris dan modelmodel soal dalam tes TOEP. Berkaitan dengan hal tersebut, media audio visual memiliki karakteristik yang dapat membantu peserta meningkatkan keterampilan mendengarkan (listening ). Menurut Wijayanti (2014) karakteristik utama media audio visual yaitu; (1) linier, (2) dinamis, (3)representatif, dan (4) interaktif.

Penyajian materi listening secara audio visual menarik dan efisien untuk meningkatkan penguasaan kosa kata dan serta kepekaan mendengarkan. Hal ini dikarenakan ketika aktifitas pada soal yang dikemas dalam bentuk short conversation maupun essay, peserta dapat memahami isi soal dengan melihat secara visual (aktifitas dan kosa kata) serta audio yang dimainkan (listening).

Media audio visual disamping dinilai efisien dalam meningkatkan kosa kata dan kepekaan mendengarkan, media tersebut juga dapat membantu peserta pelatihan untuk mengetahui trik menjawab soal listening. Hal ini dikarenakan melalui media audio visual, pemateri dapat memberikan

\section{Keterampilan listening sebagai \\ masalah klasik yang dihadapi peserta tes} TOEP/PLTI dari tahun ke tahun menjadi perhatian serius bagi dosen ber-NIDN yang belum lulus tes TOEP/PLTI di lingkungan Universitas Wiraraja.

Pelaksanaan kegiatan pengabdian ini didasarkan pada pengalaman beberapa dosen yang telah berhasil maupun belum dalam mengikuti tes tersebut dan dikombinasikan dengan teori-teori tentang peningkatan keterampilan listening. Salah satu teori yang digunakan adalah dengan meningkatkan penguasaan kosa kata terlebih dahulu. Menurut Akhmad (2020) bahwa terdapat hubungan yang signifikasn antara penguasaan kosa kata dengan keterampilan mendengarkan. Oleh karenanya, dibutuhkan media yang dapat mengakomodasi peningkatan penguasaan kosa kata sekaligus meningkatkan keterampilan mendengarkan

Metode pelaksanaan yang menjelaskan tahapan atau langkah-langkah dalam melaksanakan kegiatan pengabdian kepada masyarakat. Beserta solusi yang ditawarkan untuk mengatasi permasalahan mitra. Deskripsi secara lengkap pada bagian metodepelaksanaan.

Pada kegiatan pengabdian ini, terdapat beberapa tahapan kegiatan yatu:

a. Studi awal pengabdian

Studi awal pengabdian merupakan kegiatan awal untuk mengetahui permasalahan riil yang dhadapi peserta tes TOEP/PLTI namun gagal. Selain itu juga menganalisa kemampuan keterapilan listening dosen di lingkunagn universitas wiraraja. Kegiatan ini sebagai dasar pembuatan proposal dan materi pengabdiian 
masyarakat adalah dosen tetap ber-NIDN yang belum lolos PLTI. Dengan demikian, terdapat sekitar 15 dosen peserta pengabdian kepada masyarakat ini.

Selama proses pemberian materi PkM, seluruh peserta terlihat sangat antusias dan menyimak dengan baik isi materi. Sesekali para peserta menanyakan beberapa kosa kata yang tidak mereka ketahui namun menjadi kata kunci dalam soal. Pada pertemuan pertama, pemateri memberikan materi yang tentang response. Pada materi pertama ini, fokus soal listening adalah bagaimana peserta menjawab soal memberikan response terhadap ujaran yang disampaikan pembicara pertama. Untuk menjawab pertanyaan-pertanyaan yang diberikan peserta, pemateri menggunakan direct answer. Artnya pemateri langsung menjawab pertanyaan yang peserta PkM ajukan. Mayoritas pertanyaan yang diajukan adalah kosa kata baru dan memiliki pengucapan mirip dengan kata lainnya, seperti contohnya kata knight yang bermakna ksatria. Mayoritas peserta PkM mengira kata tersebut adalah night yang bermakna malam.

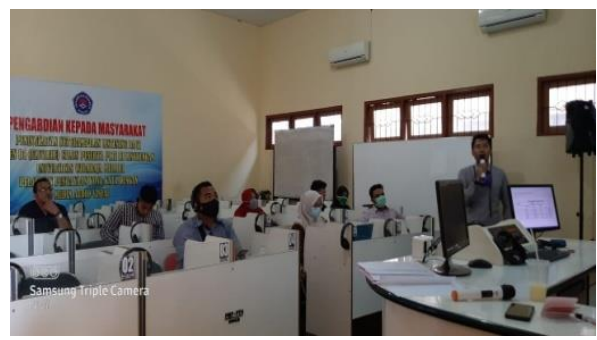

Gambar 1. Suasana Pemberian Materi

Agar hasil yang dicapai dari pelaksanaan PkM ini maksimal, maka 
berlangsung. Hal ini dapat diketahui karena pada tiap akhir kgiatan, pemateri memberikan quiz seputar kosa kata. Selain itu, mayoritas peserta kegiatan memahami trik cara menjawab soal listening.

Kegiatan pada pertemuan ke-empat mengantisipasi peserta lupa terhadap materi sebelumnya. Pada pertemuan kedua ini, pemateri memberikan mater tentang short conversation. Yaitu materi listening dengan komposisi soal fokus pada percakapan pendek. Jika dilihat dari teori tentang menjawab soal, materi yang disajikan pada pertemuan kedua masih berkaitan erat dengan materi pada pertemuan pertama

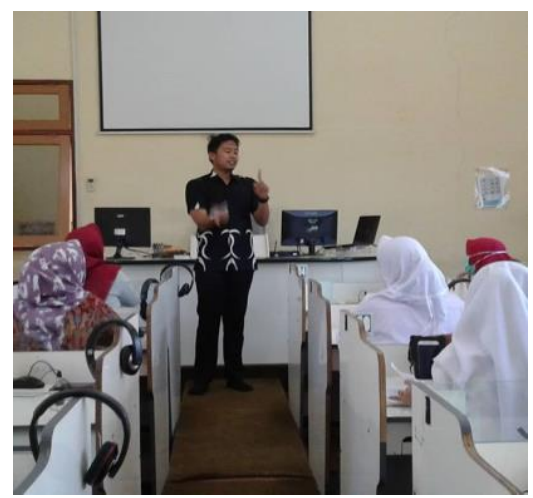

Gambar 2. Suasana Pemberian Materi

Pada pertemuan ketiga, materi yang disampaikan adalah tentang long conversation. Fokus kegiatan pada pertemuan ketiga ini terletak pada pemberian materi percakapan panjang. Secara teknis, untuk menjawab soal long conversation ini peserta diharuskan untuk memahami seluruh isi percakapan. Dikarenakan satu soal long conversation ditujukan untuk menjawab tiga soal.

Seluruh rengakaian kegiatan PkM ini disesuaikan dengan tujuan untuk meningkatkan keteampilan dosen dalam menjawab soal TOEP khsusnya listening ketika mengkuti tes PLTI. Berdasarkan kegiatan yang telah dilaksanakan, mayoritas peserta telah mengetahui beberapa kosakata yang diberikan selama kegiatan PkM adalah pemberian soal listening dengan komposisi seluruh tipe conversation. Pada kegiatan ini, tim fokus pada pemberian tes. Di akhir kegiatan, tim melakukan evaluasi terhadap skor yang diraih oleh seluruh peserta. Raihan skor tersebut dihubungkan dengan keterampilan peserta dalam memahami kosa kata dan memahami trik cara menjawab soal listening. Hasil dari pemberian soal tersebut selanjutnya dievalusasi oleh tim dan dilaksanakan perbaikan pada kegiatan selanjutnya.

Pada pertemuan ke-empat, terdapat tiga orang peserta yang masih termonitor menemui kesulitan dalam menjawab soal. Dikarenakan hal ini, tim memutuskan untuk melakukan evaluasi dengan memberikan materi yang lebih detail pada pertemuan kelima.

Kegiatan pertemuan kelima adalah
evaluasi capaian skor peserta pada
pertemuan ke-empat. Pada kegiatan kelima
ini, tim memberikan beberapa perbaikan
berdasarkan skor hasil pertemuan
sebelumnya. Selain menitik beratkan pada
raihan skor, tim melaksanakan interview
tertutup dengan peserta mengenai kesulitan-
kesulitan dalam menjawab soal.

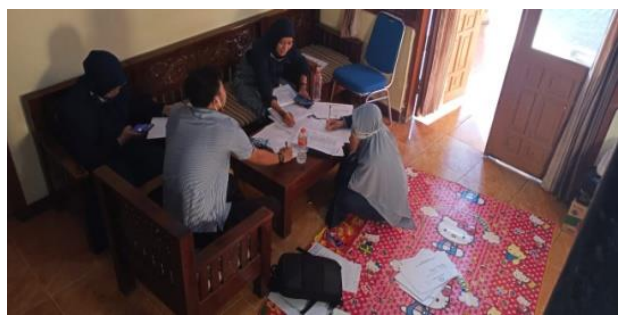

Gambar 3. Suasana interview dengan peserta

\section{Kesimpulan}


Tarigan, Djago,dkk (2006). Materi Pokok Bahasa dan Sastra Indonesia. Jakarta: Universitas Terbuka

Wijayanti,Mamik (2014). Penggunaan Media Audio Visual Untuk Meningkatkan Keterampilan Menyimak Tema Budi Pekerti Siswa di Sekolah Dasar. Jurnal Penelitian Pendidikan Guru Sekolah Dasar. Vol 2, no 3

\section{Ucapan Terima Kasih (JikaAda)}

Terimakasih kepada Laboratotium Bahasa Universitas Wiraraja yang telah menjadi mitra dalam kegiatan PKM ini. Tidak lupa pula kepada tim PKM yang telah bekerja keras melaksanakan kegiatan ini

\section{DaftarPustaka}

Fatoni, A.F. (2020). Hubungan Penguasaan Kosa Kata Dengan Keterampilan Mendengarkan Dialog Pendek Mahasiswa Akuntansi Dalam Ranah English For Accountant. Jurnal ALPEN, 4(1), 1-7

Liubiniene, Vilmante (2009). Developing Listening Skill in CLIL. Jurnal Kalbo Studijos. 15 